\title{
Analysis of the chemical properties of salted cobia (Rachycentron canadum)
}

\author{
Flávia Aline Andrade CALIXTO ${ }^{1,2 *}$ (D), Giselle Eler Amorim DIAS², Juliana de Lima Brandão GUIMARÃES ${ }^{2}$, \\ Eduardo da Silva MACHADO ${ }^{2}$, Juliana Tomaz Pacheco LATINI ${ }^{3}$, Eliana de Fátima Marques de MESQUITA ${ }^{1}$
}

\begin{abstract}
Aquaculture of cobia (Rachycentron canadum) is still incipient in Brazil, as well as the sale of its meat. However, there is a market demand for this product in the state of Rio de Janeiro. The salting process for the meat of cultivated cobia is a way of preserving and marketing the product for the growers. Thus, the present study aimed to assess the chemical properties of salted cobia meat. Market-sized cobia grown in net-tanks located in Baía de Ilha Grande, Angra dos Reis, Rio de Janeiro, Brazil were used. The fish were eviscerated (gutted), beheaded and lightly flattened. The fillets "charutos" were then subjected to brine salting for 6 days, immersed in saturated brine at refrigeration temperature. After the preparation of the product, analyzes of percent composition, chloride content and lipid profile were performed. The product had high concentrations of protein (20.16\%), lipids (19.88\%) and 6.56\% of total chloride. Lipid profile assessment showed significant percentages of palmitic (6.66\%) and oleic (4.99\%) acids. Therefore, it is concluded that the salted meat of cobia has good nutritional quality, and the product is a source of palmitic and oleic acids that help preventing cardiovascular diseases and lowering cholesterol levels.
\end{abstract}

Keywords: brine salting; nutritional composition; lipid profile; functional; functional food.

Practical Application: The traditional conservation of fish adds value to the product giving "caiçara" identity to it. Due to the intrinsic characteristics of the cultivated fish the technology for salting had to be modified just to have a better commercial product. The study performed served to attend the "bijupirä" producers demand of Costa Verde Region.

\section{Introduction}

The cobia (Rachycentron canadum) is a large, migratory coastal pelagic fish of worldwide distribution in tropical and subtropical seas (Miao et al., 2009). The species is an excellent option for commercial development and growing, due to its high performance in aquaculture in the Gulf of Mexico, in the Southeast coast of the USA, in the Caribbean and in the Atlantic Coast of South America, particularly Brazil (Benetti et al., 2011).

Cobia farming has aroused considerable interest of both the scientific community and the Brazilian private sector and public fostering institutions (Paraná, 2008). Commercial farming of cobia began in Taiwan, in the 1990s, and it is now considered an emerging species in the world aquaculture scenery. Efforts were made in this regard at the bay Baía de Ilha Grande, Rio de Janeiro, Brazil, with the purpose of assessing the performance of the referred species in this environment. The experience on the state of Rio de Janeiro is still incipient, but with encouraging experimental results related to the growth of the species, showing a great potential for the development of cobia in this region (Rombenso et al., 2009; Sampaio et al., 2010).

At the same time, researchers from other Brazilian states are encouraging the consumption of cobia through gastronomy, in a research titled "Estudo prospectivo sobre o mercado nacional do Beijupirá" (Prospective study on the national market for cobia). The "Instituto de Ciências do Mar" (Institute of Sea Sciences) of Universidade Federal do Ceará (Labomar), in

partnership with the Ministry of Fishery and Aquaculture (MPA) conducted gastronomy workshops with dishes based on cobia (Madri, 2011). "Caiçaras", a region fishing community, considered fish as a fundamental element for their diet. As a group in which refrigerated conservation technology is unknown until recently, the adoption of smoking and salting meat and fish was inevitable (Maranhão, 2016).

Salting is one of the most common forms of fish preservation. Its preservative action is characterized by partial removal of water content and increased salt concentration on the end product (reduction of water activity). To be effective, the salting process should not be considered only a way to prevent product loss, but as a primary method of preservation (Mouchrek et al., 2002).

Nevertheless, consumption of this fish is not very widespread in Brazil because the species has little importance in fishing. Thus, the technology processing applied to the meat can contribute to the popularization of the product. Combining the increased search for traditionally salted fish of the Costa Verde region and the interest of producers in learning this technology to enter this market, the study of the salting process of meat from cobia obtained in aquaculture is one way to preserve and market the fish by producers of the species in the state of Rio de Janeiro and even in Brazil. Therefore, the present study aimed to assess the chemical properties of salted cobia meat in order to demonstrate 
the nutritional and sensory quality of this fish and in the future widespread its consumption all over the population.

\section{Materials and methods}

The experiment was conducted in cultures of cobia (Rachycentrum canadum) in net-tanks located in Baía de Ilha Grande, Angra dos Reis, Rio de Janeiro, Brazil. Animals with market size (3-4 kg) were selected.

The animals caught were transported in insulated boxes with ice, according to the commercialization procedures adopted by the producer, and taken to the Laboratory of Fish and Shellfish and Aquatic Health of Universidade Federal Fluminense, totaling 6 specimens of cobia.

The brine solution was prepared with drinking water and rock and fine salt (1:1), reaching $23^{\circ} \mathrm{Be}$.

The animals were gutted, the heads were cut, the kidneys removed and then the whole fish were slightly flattened. The whole cobia were then subjected to brine salting for 6 days and during this period they were immersed in saturated brine solution (brining) at cooling temperature.

Subsequently the product was subjected to analyzes of percent composition, chloride content and lipid profile.

The percentage of moisture, crude protein, mineral matter (ashes) of the salted product was obtained with the analysis methods adopted by the AOAC (Association of Official Analytical Chemists, 1990) in triplicate, and then the average of the results was obtained. The methodology of Folch et al. (1957) was used, also in triplicate, for determining the total lipids, and the averages of the results were also obtained.

Carbohydrates (nitrogen-free extract) were calculated by fraction "NIFEXT" (Nitrogen Free Extract), and the parameter was the difference between $100 \%$ of the remaining fractions of the percentage composition (Oliveira et al., 1999).

Based on carbohydrate, protein and lipid values, the total energy value (TEV) was calculated. Carbohydrates and proteins provide $4 \mathrm{kcal} / \mathrm{g}$ energy and lipids provide $9 \mathrm{kcal} / \mathrm{g}$ (Food and Agriculture Organization of the United Nations, 2007).

Lipid profiling was performed by gas chromatography according to the methodology of the AOAC (Association of Official Analytical Chemists, 2005). The atherogenic and thrombogenic indices (AI and TI) (Batista et al., 2017; Sperry et al., 2018).

The chloride content was determined by ion chromatography (Dionex, 2015).

\section{Results and discussion}

The results of percentage composition and total energy value for salted cobia meat are shown in Table 1.

Melo et al. (2012), analyzed the percentage composition of cobias (Rachycentron canadum) weighing in average $112 \mathrm{~g}$, grown in captivity and fed a commercial diet, and obtained $78.38 \%$ of moisture, $14.23 \%$ of crude protein, $2.12 \%$ of total lipids and $1.29 \%$ of ashes, results quite different from those obtained in the present study. The difference is explained by the fact that the referred study used young animals in the analyzes, while this study used animals ready for slaughter (with a weight of $3-4 \mathrm{~kg}$ ), and this fact would explain the large difference in total lipid content. Besides, since it is a salty product, the moisture content is automatically reduced and the ash content increases, as demonstrated by Ekpenyong \& Ibok (2012) who compared the percentage composition of frozen and salted meat of African catfish (Clarias gariepinus) and obtained a significant decrease in moisture content and increased ash content.

Analysis of the percentage composition of wild adult cobias showed $77.69 \%$ of moisture, $17.03 \%$ of crude protein, $5.17 \%$ of total lipids, $0.84 \%$ of ashes (Melo et al., 2014), values that are still quite different from those obtained in the present study with salted products, but showing less divergent results regarding crude protein levels and increased fat content.

Analysis of the composition of farmed cobia weighing more than $3 \mathrm{~kg}$ (weight range of this study) obtained $70.82 \%$ of moisture and $57 \%$ of total protein, $41 \%$ of total lipids and $3 \%$ of ashes, for the dry sample, values higher than those obtained in the present study except for ashes (Oliveira, 2012).

A comparative study of carcasses of juveniles of Rachycentron canadum fed diets containing different levels of fish and soy oil for 42 days (Silva et al., 2011) found percentage values similar to the levels of crude protein (16.7-21.4) and close to the level of ashes (4.6-7.9) of salted cobia meat.

Aiura et al. (2008) who worked with brining (saturated brine solution) of Nile tilapia fillet obtained a similar percentage value for protein $(20.1 \%)$ prior to product drying and a higher percentage of ashes (13.3\%).

Santana et al. (2010) subjected cobias to salting using four treatments with different salt concentrations; the two mildest salting treatments reached levels of moisture $(66.41 \%$ and $64.67 \%)$ higher than those of the present study (45.98\%).

Freitas et al. (2011) who used wet salting in "pacu" (Piaractus mesopotamicus) fillets obtained the following percentage values: $58.79 \%$ for moisture, $16.22 \%$ for proteins, $13.12 \%$ for lipids and $19.48 \%$ for ashes. The values obtained for proteins and lipids were lower than those obtained for salted cobia meat, and higher for moisture and ashes. Gomide (2005) who used wet salting in "piracanjuba" (Brycon orbignyanus) fillets obtained a similar percentage of moisture (47.38\%) and higher percentages of crude protein $(25.30 \%)$ and ashes $(20.90 \%)$.

Table 1. Average results of physical and chemical analyzes of salted meat of cobia (Rachycentron canadum) in $100 \mathrm{~g}$.

\begin{tabular}{lc}
\hline \multicolumn{1}{c}{ Nutritional component } & Results \\
\hline Moisture & $45.98 \% \pm 0.42$ \\
Crude protein & $20.16 \% \pm 0.007$ \\
Crude lipid & $19.88 \% \pm 0.45$ \\
Mineral matter & $8.71 \% \pm 0.07$ \\
Nitrogen free extract & $5.27 \% \pm 0.8$ \\
Total chloride & $6.56 \% \pm 10 \%$ \\
Total Energy Value & $280 \mathrm{Kcal} / \mathrm{g}$ \\
\hline
\end{tabular}


Despite the chloride content of less than $7 \%$ of salted cobia meat, Gonçalves et al. (2014) found a low percentage of chlorides in cobia fresh meat $(0.84 \%)$.

The sodium content of salted cobia was not so significant than those obtained in studies involving dried and salted fish. Oliveira et al. (2008) obtained $17.02 \%$ of chlorides in the processing of dried and salted "mandim" (Arius spixii). Using wet salting, Freitas et al. (2011) found $24.39 \%$ of chlorides in salted "pacu" fillets (Piaractus mesopotamicus).

The chloride concentration fin salted cobia meat was low because a product kept at room temperature should remain longer in brine or else it should be previously dried and subjected to another brining until higher chloride levels were obtained. Another facilitator of salt penetration is fillet salting.

The lipid profile of salted cobia meat are shown in Table 2.

The lipid profile of fish is usually composed of saturated or unsaturated long-chain fatty acids (14-22) carbons (Botta et al., 1986), which is similar to the range observed in the present study. Oliveira et al. (2008) in a study of dried and salted "mandim"

Table 2. Average results for analyzes of the lipid profile of the meat of salted cobia (Rachycentron canadum) meat.

\begin{tabular}{|c|c|}
\hline Lipids & Results \\
\hline Lauric Acid (C12:0) & $0.05 \%$ \\
\hline Myristic Acid (C14:0) & $1.25 \%$ \\
\hline Pentadecanoic Acid (C15:0) & $0.22 \%$ \\
\hline Palmitic Acid (C16:0) & $6.66 \%$ \\
\hline Palmitoleic Acid (C16:1) & $1.27 \%$ \\
\hline Margaric Acid (C17:0) & $0.20 \%$ \\
\hline Stearic Acid (C18:0) & $1.63 \%$ \\
\hline Elaidic Acid (C18:1n9t) & $0.02 \%$ \\
\hline Oleic Acid (C18:1n9c) & $4.99 \%$ \\
\hline Linoleic Acid (C18:2n6c) & $0.71 \%$ \\
\hline LNA Alpha Linolenic Acid (C18:3n3) & $0.04 \%$ \\
\hline Arachidic Acid (C20:0) & $0.11 \%$ \\
\hline Cis-11-Eicosenoic Acid (C20:1n9) & $0.19 \%$ \\
\hline 11,14 cis Eicosadienoic Acid (C20:2) & $0.02 \%$ \\
\hline 8,11,14-Eicosatrienoic Acid (C20:3n6) & $0.03 \%$ \\
\hline Behenic Acid (C22:0) & $0.04 \%$ \\
\hline Erucic Acid (C22:1n9) & $0.05 \%$ \\
\hline 5,8,11,14,17 Acid- (EPA C20:5n3) & $0.02 \%$ \\
\hline Tricosanoic Acid (C23:0) & $0.02 \%$ \\
\hline Lignoceric Acid (C24:0) & $0.08 \%$ \\
\hline Nervonic Acid (C24:1n9) & $0.09 \%$ \\
\hline Monounsaturated Fat & $6.59 \%$ \\
\hline Poly-unsaturated Fat & $0.84 \%$ \\
\hline Unsaturated Fats & $7.43 \%$ \\
\hline Saturated Fats & $10.27 \%$ \\
\hline Trans Fats & $0.02 \%$ \\
\hline Omega 3 & $0.06 \%$ \\
\hline Omega 6 & $0.73 \%$ \\
\hline Omega 9 & $5.34 \%$ \\
\hline $\mathrm{AI}^{*}$ & 1.76 \\
\hline $\mathrm{TI}^{\star *}$ & 2.57 \\
\hline
\end{tabular}

${ }^{\star}$ AI: Atherogenic Indices; ${ }^{* *}$ TI: Thrombogenic Indices.
(Arius spixii) found a wider range of fatty acids with chains ranging from 6 to 24 carbons, contrasting with the range obtained for cobia. On the other hand, a higher percentage of saturated than unsaturated fats and a higher percentage of palmitic acid followed by oleic acid, which was also observed in cobia.

The amounts of omega 3 and 6 found in salted cobia meat are lower than those found in studies with fresh cobia, probably due to lipid oxidation caused by the salting process. Regarding the determination of the lipid profile of the samples, Melo et al. (2012) quantified the total percentage of omega 3 (10.55\%) and omega $6(22.45 \%)$ for juvenile cobia in captivity and fed a commercial diet, and Melo et al. (2014) determined $40.67 \%$ of omega 3 and $7.3 \%$ of omega 6 in wild adult cobia. According to Oliveira (2012) cobia weighing more than $3 \mathrm{~kg}$ in aquaculture have $140 \%$ omega 3 and $300 \%$ omega 6 on dry weight basis. Although salted "bijupirá" has a lower omega 3 content than fresh one, it remains a good source of this fatty acid, as the Brazilian population cannot attend the level recommended for minimum consumption.

Lauric, myristic and palmitic fatty acids are present in salted cobia, and palmitic acid being the most abundant. According to Santos et al. (2012), these fatty acids can cause slightly lower LDL-c levels and raise the levels of blood HDL-c; thus, the product is beneficial for individuals with cardiovascular disorders, e.g. those with an inherited form of hypercholesterolemia.

Oleic acid (omega 9) was the second most abundant fatty acid in the sample of salty meat, and is the monounsaturated fatty acid that most frequently occurs in the diet. This compound is very common in functional foods such as olive oil. According to Cardoso (2004), this fatty acid lowers LDL levels as intensely as polyunsaturated acids, without lowering HDL levels. Furthermore, it is less susceptible to oxidation than polyunsaturated acids. This implies less risk of cardiovascular diseases and cerebrovascular accidents.

The use of formulations rich in monounsaturated lipids, such as omega 9, compared to polyunsaturated lipids (omega 3 and 6) showed lower inflammatory response and lower production of free radicals (Curi et al., 2002). It is widely known that the Mediterranean diet is characterized by high consumption of oleic acid, and the people who have these dietary habits have lower prevalence of obesity, metabolic syndrome, type 2 diabetes and cardiovascular events. Products like whole grains, fruits, fish and vegetables are part of the diet of the population of the region (Lottenberg, 2009).

Fish is the biggest source of omega-3 fatty acids, particularly eicosapentaenoic (EPA) and docosaexaenoic (DHA) acids (Cardoso, 2004). Salted cobia showed a very low percentage of these fatty acids, probably because it is a breeding animal fed by feed and lipid oxidation during the salting process.

Present in small levels in cobia, omega 6 (linoleic acid) can help lowering blood LDL levels. However, it should not be consumed excessively, as it may cause premature cell aging, structural abnormalities in membranes, changes in the genetic code and formation of hormone compounds that stimulate platelet adhesion and aggregation (Cardoso, 2004). 
The Brazilian legislation (Brasil, 1999) does not define functional food or functional properties; it only defines the claim of functional property as related to the metabolic or physiological role that a nutrient or non-nutrient plays on the growth, development, maintenance and other normal functions of the human body; and the only product likely to be approved by ANVISA with functional property claim is omega 3 for fatty acids. Nevertheless, other nutrients such as palmitic acid and oleic acid could be considered to possess functional properties, as they help reduce risk factors for diseases.

However, ANVISA's resolution provides on Technical Regulation of Complementary Nutritional Facts (Brasil, 2012) which is any representation that states, suggests or implies that a food has particular nutritional properties, especially with regard to its energy value and/or to proteins, fats and carbohydrates contents as well as to vitamins and minerals contents. Then, some foods can be defined as source or high content of omega 3,6 and 9 on the labeling depending on the amount of these fatty acids present in the product, like salted cobia.

According to Ulbricht \& Southgate (1991), the levels of atheroma and thrombosis in fish indicate the overall dietary quality of lipids and their potential effect on the development of coronary diseases. The AI and TI values were in the range of 1.76 to 2.57 , higher than that found in other species by several authors (Durmuş, 2019; Turan et al., 2011). These rates are related to the percentage of lipids present in food and although the fish species studied in this work has a significant lipid value in its composition, they are good quality lipids, primarily polyunsaturated fatty acids, being a good source of omega 9.

Therefore, the recommendation for the intake of polyunsaturated fatty acids is more than $10 \%$ within the distribution of total fatty acids in a normal diet and according to the International Society for the Study of Fatty Acids and Lipids (2004) the recommended intake of PUFA for healthy adults is $2 \%$ of the total energy for omega 6 and $0.7 \%$ of the total energy for omega 3 and that the "beijupirá" has a good concentration of them, and its consumption is beneficial, even though their IA and IT rates are higher than other types of fish. Considering that this species has a better fatty acid composition when compared to chicken, beef and pork meat, composed mainly of saturated fatty acids (Harari et al., 2019) and that the fish oil in general remains an excellent strategy for control and reduction of atherogenic factors (Souza et al., 2020). All of these features make this fish a good nutritional source for preventing atherosclerosis.

In 2012, RDC 54, ANVISA (Brasil, 2012) updated the Brazilian Complementary Nutritional Information statement. Among the changes of RDC27/99 was the way of declaration of protein source foods. Thus, not only protein quantity is taken into account, but also the quality of the protein in question, which to be considered as an excellent source of protein, must have all the essential amino acids in its composition. Considering this assumption and that the ordinary Brazilian diet, although hyperproteic, is composed of an excess of low quality proteins, such as that from sausages and ultra-processed products, the "bijupirá" could be an excellent option for the diet to consume proteins of high biological value, and could be widespread and stimulated overall.
Considering this assumption and knowing that the Brazilian diet, although hyperproteic, is composed of an excess of low quality proteins, such as that from sausages and ultra-processed products, bijupirá enters this scenario as an excellent option for the diet. consumption of proteins of high biological value, and its consumption should be more widespread and stimulated.

\section{Conclusion}

Salted cobia meat was found to have a good nutritional quality. Besides, it is a source of palmitic and oleic acids that help control cardiovascular diseases and cholesterol levels.

\section{Acknowledgements}

To FAPERJ, for the financial support to the project; to CAPES, for the doctoral fellowship; to producers Carlos Kazuo and Marcelo Lacerda, for providing the fish for the research.

\section{References}

Aiura, F. S., Carvalho, M. R. B., Viegas, E. M. M., Kirschnik, P. G., \& Lima, T. M. A. (2008). Conservação de filés de tilápia-do-nilo (Oreochromis niloticus) em salga seca e salga úmida. Arquivo Brasileiro de Medicina Veterinária e Zootecnia, 60(6), 1531-1537. http://dx.doi. org/10.1590/S0102-09352008000600033.

Association of Official Analytical Chemists - AOAC. (1990). Official methods of analysis of the Association of Official Analytical Chemists (15th ed., Methods 930.15, 954.01, 942.05). Washington: AOAC.

Association of Official Analytical Chemists - AOAC. (2005). Official methods of analysis of the Association of Official Analytical Chemists (18th ed., Method 996.06). Washington: AOAC.

Batista, A. L. D., Silva, R., Cappato, C. P., Ferreira, M. V. S., Nascimento, K. O., Schmiele, M., Esmerino, E. A., Balthazar, C. F., Silva, H. L. A., Moraes, J., Pimentel, T. C., Freitas, M. Q., Raices, R. S. L., Silva, M. C., \& Cruz, A. G. (2017). Developing a synbiotic fermented milk using probiotic bacteria and organic green banana flour. Journal of Functional Foods, 38, 242-250. http://dx.doi.org/10.1016/j. jff.2017.09.037.

Benetti, D. D., Orhun, M. R., Zink, I., Cavalin, F. G., Sardenberg, B., Palmer, K., Denlinger, B., \& Bacoat, D. (2011) Aquaculture of Cobia (Rachycentron canadum) in the Americas and the Caribbean. Retrieved from: http://aquaculture.rsmas.miami.edu/media/Aquaculture-inthe-Americas-Benetti-etalCobia2007.pdf

Botta, J. R., Kennedy, K., \& Squires, B. E. (1986). Efect of method of catching and time of season on the composition of Atlantic cod (Gadus morhua). Journal of Food Science, 52(4), 922-927.

Brasil. Ministério da Saúde. Agência Nacional de Vigilância Sanitária ANVISA. (1999). Resolução nº 19, de 30 de abril de 1999. Aprova o Regulamento Técnico de procedimentos para registro de alimento com alegação de propriedades funcionais e ou de saúde em sua rotulagem. Diário Oficial [da] República Federativa do Brasil.

Brasil. Ministério da Saúde. Agência Nacional de Vigilância Sanitária ANVISA. (2012, November 12). Resolução da Diretoria Colegiada $\mathrm{RDC} \mathrm{n}^{\circ}$ 54, de 12 de novembro de 2012. Dispõe sobre o Regulamento Técnico sobre Informação Nutricional Complementar. Diário Oficial [da] República Federativa do Brasil. Retrieved from http://portal. anvisa.gov.br/documents/\%2033880/2568070/rdc0054_12_11_2012. $\mathrm{pdf} / \mathrm{c} 5 \mathrm{ac} 23 \mathrm{fd}-974 \mathrm{e}-4 \mathrm{f} 2 \mathrm{c}-9 \mathrm{fbc}-48 \mathrm{f} 7 \mathrm{e} 0 \mathrm{a} 31864$

Cardoso, J. (2004). Nutrição e doença cardiovascular: $2^{a}$ parte. Medicina Interna, 11(3), 123-131. 
Curi, R., Pompéia, C., Miyasaka, C. K., \& Procopio, J. (2002). Ácidos graxos e câncer. In R. Curi. Entendendo a gordura: os ácidos graxos (cap. 37, pp. 523-538). São Paulo: Manole.

Dionex. (2015). Determination of sulfate and chloride in ethanol by ion chromatography (Application Note, No. 175). ThermoFisher Scientific. Retrieved from http://www.dionex.com/en-us/webdocs/39541AN175_LPN1827-R2.pdf

Durmuş, M. (2019). Fish oil for human health: omega-3 fatty acid profiles of marine seafood species. Food Science and Technology (Campinas), 39(Suppl. 2), 454-461. http://dx.doi.org/10.1590/fst.21318.

Ekpenyong, E., \& Ibok, C. O. (2012). Effect of smoking, salting and frozen-storage on the nutrient composition of the African catfish (Clarias gariepinus). Journal of Food Agriculture and Environment, 10(1), 64-66.

Folch, J., Lees, M., \& Sloane Stanley, G. H. (1957). A simple method for the isolation and purification of total lipides from animal. The Journal of Biological Chemistry, 226(1), 497-509. PMid:13428781.

Food and Agriculture Organization of the United Nations - FAO. (2007). The Codex Alimentarius Commission and the FAO/WHO Food Standards Programme. Roma: FAO. Special Publications. Food Labelling: complete texts. Retrieved from http://www. codexalimentarius.net/web/publications_es.jsp

Freitas, J. M. A., Higuchi, L. H., Feiden, A., Maluf, M. L. F., Dallagnol, J. M., \& Boscolo, W. R. (2011). Salga seca e úmida de fiés de pacu (Piaractus mesopotamicus). Semina: Ciências Agrárias, 32(2), 613620. http://dx.doi.org/10.5433/1679-0359.2011v32n2p613.

Gomide, C. A. (2005). Estudo da qualidade física, química e mi crobiológica de filés de piracanjuba (Brycon orbignyanus Valenciennes, 1849) submetidos à salga seca e úmida (Tese de doutorado). Faculdade de Zootecnia e Engenharia de Alimentos, Universidade de São Paulo, Pirassununga. Retrieved from http://www.teses.usp.br/teses/ disponiveis/livredocencia/74/tde-22062011-121644/fr.php

Gonçalves, A. A., Dantas, A. B. No., Guilherme, D. D., Marques, M. K., Sales, T. M. O., \& Lima, J. T. A. X. (2014) Técnicas de processamento e beneficiamento visando agregação de valor do beijupirá, Rachycentron canadum. In A. J. P. Nunes. Ensaios com beijupirá, Rachycentron canadum (cap. 11, pp. 167-197). Fortaleza: Ministério da Pesca e Aquicultura/CNPQ/UFC.

Harari, A., Frenkel A. L., Barshack, I., Sagee, A., Cohen, H., Kamari, Y., Harats, D., Kfir, M. K., \& Shaish, A. (2019) Addition of fish oil to atherogenic high fat diet inhibited atherogenesis while olive oil did not, in LDL receptor KO mice. Nutrition, Metabolism and Cardiovascular Diseases, 30(4), 709-716.

International Society for the Study of Fatty Acids and Lipids - ISSFAL. (2004). Recommendations for intake of polyunsaturated fatty acids in healthy adults. Retrieved from http://archive.issfal.org/statements/ pufa-recommendations/statement-3

Lottenberg, A. M. P. (2009). Importância da gordura alimentar na prevenção e no controle de distúrbios metabólicos e da doença cardiovascular. Arquivos Brasileiros de Endocrinologia \& Metabologia, 53(5), 595-607. http://dx.doi.org/10.1590/S0004-27302009000500012. PMid:19768250.

Madri, R. (2011). Labomar promove evento de gastronomia sobre beijupirá de 9 a 12 de agosto. Fortaleza: LABOMAR. Retrieved from http:// www.labomar.ufc.br/index.php?option=com_content $\&$ task=view \&id=157\&ItemiI $=3$

Maranhão, R. F. A. (2016). Consumo de pescados na relação pescadores $\mathrm{x}$ turismo em Cananéia - SP. In Anais do VIII Encontro Nacional de Estudos do Consumo. São Paulo: Síntese Eventos. Retrieved from http:// www.enec2016.sinteseeventos.com.br/resources/anais/7/1476380469_ ARQUIVO_Consumopescados_relacoescomturismo_Cananeia.pdf
Melo, F. V. S. T., Costa, C. N., Silva, J. R., Druzian, J. I., \& Abreu, R. D. (2012). Composição centesimal e perfil de ácidos graxos em bijupirá (Rachycentron canadum) juvenis selvagens e cultivados. Enciclopédia Biosfera, 8(15), 458-465.

Melo, F. V. S. T., Fonteles, S. B. A., Albinati, R. C. B., Druzian, J. I., \& Abreu, R. D. (2014). Composição centesimal e perfil de ácidos graxos em bijupirá (Rachycentron canadum) adultos selvagens. Enciclopédia Biosfera, 10(18), 993-1000.

Miao, S., Jen, C. C., Huang, C. T., \& Hu, S. (2009). Ecological and economic analysis for cobia Rachycentron canadum commercial cage culture in Taiwan. Aquaculture International, 17(2), 125-141. http://dx.doi.org/10.1007/s10499-008-9185-7.

Mouchrek, V. E. Fo., Chaar, J. S., Nascimento, A. R., Mouchrek, J. E. Fo., Costa, I. S., Martins, A. G. L. A., \& Marinho, S. C. (2002). Avaliação microbiológica do pirarucu (Arapaima gigas) seco e salgado, comercializado nas feiras livres da cidade de Manuas-AM. Cadernos de Pesquisa, 13(1), 14-21.

Oliveira, E. C. M., Oliveira, E. R., Lima, L. C. O., \& Boas, E. V. B. V. (1999). Composição centesimal do cogumelo do sol (Agaricus blazei). Revista Universidade Alfenas, 5, 169-172.

Oliveira, F. R., Lira, G. M., Torres, E. A. F. S., Soares, R. A. M., Mendonça, S., Silva, K. W. B., Simon, S. J. G. B., Santos, T. M. P., \& Cabral, C. R. Jr. (2008). Efeito do beneficiamento sobre o valor nutricional do peixe mandim (Arius spixii). Brazilian Journal of Pharmaceutical Sciences, 44(4), 655-677.

Oliveira, R. L. M. (2012). Morfometria, rendimento de carcaça e composição do filé do beijupirá (Rachycentron canadum) cultivados em tanques-rede em mar aberto no litoral de Pernambuco (Dissertação de mestrado). Universidade Federal Rural do Pernambuco, Recife. Retrieved from http://200.17.137.108/tde_busca/arquivo.php? codArquivo=1428

Paraná. Governo do Estado. Secretaria de Estado de Administração Penitenciária - SEAP. (2008). Mais pesca e aquicultura - Plano de desenvolvimento sustentável - Uma rede ações para o desenvolvimento do setor. Curitiba: SEAP. Retrieved from http://tuna.seap.gov.br/ seap/html/publicacoes/publicacoes.html

Rombenso, A. N., Moreira, C. B., Miranda-Filho, K. C., \& Sampaio, L. A. N. (2009). Avaliação do crescimento de bijupirá (Rachycentron canadum) alimentados com uma dieta comercial e peixe fresco. In Anais da Conferencia Latinoamericana sobre Cultivo de Peces Nativos. Porto Alegre: UFRGS. Retrieved from http://propesp.furg. br/anaismpu/cd2009/cic/agrarias/848-974-1-SM.pdf

Sampaio, L. A. N., Tesser, M. B., \& Wasielesky Júnior, W. (2010). Avanços da maricultura na primeira década do século XXI: piscicultura e carcinocultura marinha. Revista Brasileira de Zootecnia, 39(Supl. spe), 102-111. http://dx.doi.org/10.1590/S1516-35982010001300012.

Santana, F. M. S., Lins, L. H. C., Carvalho-Neto, P. M., Santana, C. A. S., Silva, B. C. L., Santana, N. M., Araújo-Neto, E. T., Silva, S. L., Silva, A. C. G., Lima, H. C., \& Melo, K. S. G. (2010). First record about yield and moisture of cobia submmited to salting pross. Revista Brasileira de Engenharia de Pesca, 5(2), 37-42.

Santos, R. D., Gagliardi, A. C. M., Xavier, H. Z., Casella, A. Fo., Araújo, D. B., Cesena, F. Y., Alves, R. J., Pereira, A. C., Lottemberg, A. M. P., Chacra, A. P. M., Faludi, A. A., Sposito, A. C., Ribeiro, F. F. Fo., Fonseca, F. A. H., Giuliano, I. C. B., Catani, L. H., Bertolami, M. C., Miname, M. H., Izar, M. C. O., Monte, O., Maranhão, R. C., Martinez, T. L. R., Machado, V. A., Rocha, V. Z., \& Salgado, W. Fo. (2012). I Diretriz Brasileira de Hipercolesterolemia Familiar (HF). Arquivos Brasileiros de Cardiologia, 99(2, Suppl. 2), 1-28. http:// dx.doi.org/10.5935/abc.20120202.

Silva, R. F. Jr., Nova, W. V., Farias, J. L., Costa-Bomfim, C. N., Tesser, M. B., Druzian, J. I., Correia, E. S., \& Cavalli, R. O. (2011). Substituição do 
óleo de peixe por óleo de soja em dietas para beijupirá (Rachycentron canadum). Arquivo Brasileiro de Medicina Veterinária e Zootecnia, 63(4), 980-987. http://dx.doi.org/10.1590/S0102-09352011000400025.

Souza, D. R., Pieri, B. L. S., Comim, V. H., Marques, S. O., Luciano, T. F., Rodrigues, M. S., \& Souza, C. T. (2020). Fish oil reduces subclinical inflammation, insulin resistance, and atherogenic factors in overweight/obese type 2 diabetes mellitus patients: A pre-post pilot study. Journal of Diabetes and Its Complications, 34(5), 107553. http://dx.doi.org/10.1016/j.jdiacomp.2020.107553. PMid:32014347.

Sperry, M. F., Silva, H. L. A., Balthazar, C. F., Esmerino, E. A., Verruck, S., Prudencio, E. S., Neto, R. P. C., Tavares, M. I. B., Peixoto, J. C., Nazzaro, F., Rocha, R. S., Moraes, J., Gomes, A. S. G., Raices, R. S. L., Silva, M. C., Granato, D., Pimentel, T. C., Freitas, M. Q., \& Cruz,
A. G. (2018). Probiotic Minas Frescal cheese added with L. casei 01 : Physicochemical and bioactivity characterization and effects on hematological/biochemical parameters of hypertensive overweighted women - A randomized double-blind pilot trial. Journal of Functional Foods, 45, 435-443. http://dx.doi.org/10.1016/j.jff.2018.04.015.

Turan, H., Kaya, Y., \& Erdem, M. E. (2011). Proximate composition, cholesterol, and fatty acid content of brown shrimp (Crangon crangon L. 1758) from Sinop Region, Black Sea. Journal of Aquatic Food Product Technology, 20(1), 100-107. http://dx.doi.org/10.108 0/10498850.2010.526753.

Ulbricht, T. L. V., \& Southgate, D. A. T. (1991). Coronary heart disease: seven dietary factors. Lancet, 338(8773), 985-992. http://dx.doi. org/10.1016/0140-6736(91)91846-M. PMid:1681350. 